\title{
Social change at the end of the Middle Jomon: a perspective from resilience theory
}

\author{
Takamune Kawashima \\ Faculty of Humanities and Social Sciences, University of Tsukuba, JP \\ k_takamune@hotmail.com
}

\begin{abstract}
It is widely known that social change occurred in the end of the Middle Jomon, which can be seen in archaeological evidence such as settlements, pottery types, and so on. Most archaeologists have recognised this change as a result of climate change. It is said that a cooling trend in this period had a great influence on food acquisition and caused low chestnut harvests, which was a staple. However, the notion that climate was the critical factor is not sufficient to explain the social change that occurred at the end of the Middle Jōmon, because similar types of society existed after this cooling trend, although the population numbers decreased. It is also important to consider human adaptation to the environment, especially in the case of hunter-gatherer societies. In this paper, I will describe the outline of the arguments supporting the environment theory among Japanese archaeologists, and explore how Jōmon people overcame this period and constructed a new society, based on resilience theory.
\end{abstract}

IZVLEČEK - Znano je, da se je družbena sprememba zgodila na koncu razvoja srednje Jōmon kulture, kar lahko prepoznamo $v$ arheoloških podatkih kot so naselja, tipi posod, itd. Večina arheologov je prepoznala to spremembo kot posledico klimatskih sprememb. Ohladitve v tem obdobju so imele velik vpliv na pridobivanje hrane in so povzročile slabše letine kostanja, ki je bil osnovno živilo $v$ tej kulturi. Vendar pogled, da je sprememba klime predstavljala ključni dejavnik, ni zadosten za razlago o tem, kako je prišlo do družbenih sprememb na koncu srednjega Jōmona, saj so se podobni tipi družbene ureditve obdržali tudi po ohladitvi kljub zmanjšanju števila prebivalcev. Upoštevati je potrebno tudi človeško prilagodljivost na okolje, sploh pri lovsko-nabiralniških družbah. V članku opisujem okvirne razprave, ki so v prid okoljskim teorijam med japonskimi arheologi, in s pomočjo teorije prožnosti raziskujem, kako so ljudje v kulturi Jōmon obvladali to obdobje in zgradili novo družbo.

KEY WORDS - Jōmon; social change; resilience theory; hunter-gatherers; prehistory

\section{Social change at the end of the Middle Jōmon}

It is widely known that social change occurred at the end of the Middle Jōmon. Many archaeologists (Yamamoto 1980; Yasuda 1981; Suzuki 1986; 1991; Teshigawara 1992; Abiko 2011; Abe 2008) describe how large settlements disappeared and the size of settlements decreased, while settlements in the middle Middle Jōmon had large numbers of pit houses. Most archaeologists believe that climate change caused this social change. It is said that a cooling trend in this period had great influence on food acquisition, and caused low chestnut harvests, which was a staple food in the Middle Jōmon. They reason that the Jomon economy could not have sustained such large-scale settlements, and that Jōmon people were forced to change their subsistence and settlement system in order to adapt to climate change, which is thought to have been a cooling trend.

This kind of interpretation has been dominant since the 1980s. However, the notion that climate was the critical factor is not sufficient to explain the social change which occurred at the end of the Middle Jōmon, because similar types of society existed after 
the cooling trend although the number of houses decreased. It is also important to consider human adaptation to the environment, especially in the case of hunter-gatherer societies. Only a few archaeologists (Kobayashi 1985; Imamura 1997) proposed alternative view, which focuses on the environmental adaptability of hunter-gatherers. They assert that Jōmon society could have adapted to climate change, since their subsistence was based on hunting, gathering and fishing.

However, no theory has explained this social change so far, except climate change which is based on pollen analysis (Yasuda 1981; 1997). According to the pollen analysis, increasing amounts of horse chestnuts (Aesculus hippocastanum) from Late Jōmon sites are inferred, relating to climate change (Sasaki 2007). Although the main construction material for houses (and other structures) after the Late Jo mon remained chestnut wood. Therefore, it is not sufficient to explain the increasing quantity of horse chestnuts merely as a result of climate change ( $\mathrm{Ka}$ washima 2009).

\section{Resilience theory and archaeology}

According to Walker and colleagues, a resilient system is defined as a system that can absorb disturbance and undergo some degree of change while still retaining the same general functions and structure (Walker et al. 2004). Resilience is also explained as the ability of a system to undergo change and keep the same functions, structure and feedbacks (Gunderson, Holling 2002; Walker, Salt 2006).

Resilience theory suggests four stages: exploitation, conservation, release and reorganisation. These stages are highly theoretical, but suggest important concepts for understanding processes of reformation or reorganisation in cultures. Previous archaeological research in Japan focused mainly on the exploitation and conservation stages. However, resilience theory can be also applied to understanding prehistoric societies.

In this paper, I will examine the process of changing material culture in the Jōmon, using the methodology proposed by Hegmon and colleagues (2008), which aims to measure degrees of rigidity. Rigidity is thought to be among the factors that reduce resilience. Jōmon society must have been much simpler than the societies which are examined in the following examples, but I will test the method for the analysis of hunter-gatherer societies.
Case studies from the Southwest of the US

Hegmon et al. (2008) investigated some parameters of three societies in the southwest region of the United States: Mimbres, Mesa Verde and Hohokam. They chose the periods of transformation: the Mimbres Classic (AD 1000-1130) ended with changes in material culture and settlement reorganisation, which can be related to change in the natural environment (Schollmeyer 2011); Late Pueblo III (AD 1200-1300) ended with large-scale emigration and depopulation; and the Hohokam Classic (AD 1150-1450) ended with population decline.

They assessed 20 archaeological measurable variables (Tab. 1), using data from three regions for almost the same period. A key concept here for explaining the difference in changes in various societies is 'rigidity trap'. They conclude that such parameters support their proposition that an association existed between the degree of rigidity and the severity of transformations. As a result of their comparison of three cases, they concluded that the Mimbres transformation was the least rigid case, which led to the moderate reorganisation of their settlements and change in their material culture. I will try to evaluate the rigidity of Middle Jōmon societies in the same way.

\section{Resilience of Jömon society: comparison with societies in the Southwest of the US}

The subsistence and social organisation of the Jōmon differs from those of the three cultures of the US Southwest. We cannot apply the same variables. For example, there were no clear public structures in the Middle Jomon in the Kanto region. So, we cannot measure the degree of 'restricted access to public architecture', 'people per public structure', or 'average number of public structures per aggregated site'.

It is well known that the Middle Jōmon was characterised by many large-scale settlements. Settlement plans were usually circular, and sometimes areas were divided for storage, graves, and pit houses. Although the area is different, the Nishida site in Iwate prefecture is well known. This kind of large settlement appears in the middle period of the Middle Jōmon, and disappears after the Kasori E3 phase.

For example, at the Teranohigashi site, which is known as a site with a ring-shaped earth mound, Middle Jōmon pit houses were excavated in the southern part of the site (Ehara 2001). The Middle Jōmon settlement at Teranohigashi could have been 




Tab. 1. Parameters of rigidity (after Hegmon et al. 2008.Tabs. 1-6). 
a circular settlement. Like other Middle Jōmon sites, scarce archaeological evidence of residence such as pit houses and pits from the end of the Middle Jōmon to the beginning of the Late Jomon was found, while in the northern part of the site, a ring-shaped earth mound and most pit houses were built after the Horinouchi phase (Fig. 1).

Using variables presented by Hegmon et al. (2008), I try to examine the degree of rigidity of Middle Jōmon society.

\section{Scale and displacement: demographic and set- tlement data}

The size of the regional population in the Jomon prior to the transformation is difficult to estimate. Some archaeologists assume that in the Middle Jōmon, large settlements were formed, but in a very long time period, which means the so-called large settlements could be the result of accumulation of pit houses over time. The minimum size of a settlement is about five contemporary pit houses grouped together. On the other hand, settlements could have a maximum of 12 houses. It is difficult to identify the phase to which each settlement belongs. If the assumption of population increase is correct, rapid population decline after the Middle Jōmon presents another problem. The issue of Jōmon population needs further research. While we should consider this problem, it is notable that houses were built repeatedly on the same sites in the Middle Jomon, even if they were mobile. This can be related to the rigidity of the society.

After the Kasori E3 phase, these large settlements disappeared. At such sites thereafter, only a small number of archaeological remains are found. But, there is no clear archaeological evidence of emigration. People probably dispersed and created smallscale and short- term settlements.

\section{Degree of change: ceramic and architectural data}

Stylistic and organisational changes in the material culture can be seen in the Middle Jomon period. The ceramic styles gradually faded away, and regional differences are less recognisable. Mobility probably increased, although the basic style of a pit house remained unchanged, so change in household organisation could have been minimal.

\section{Physical suffering}

There is almost no trace of physical suffering in the Jōmon, such as health problems and violence. We should study decayed teeth, which can be related to amounts of carbohydrates consumed.

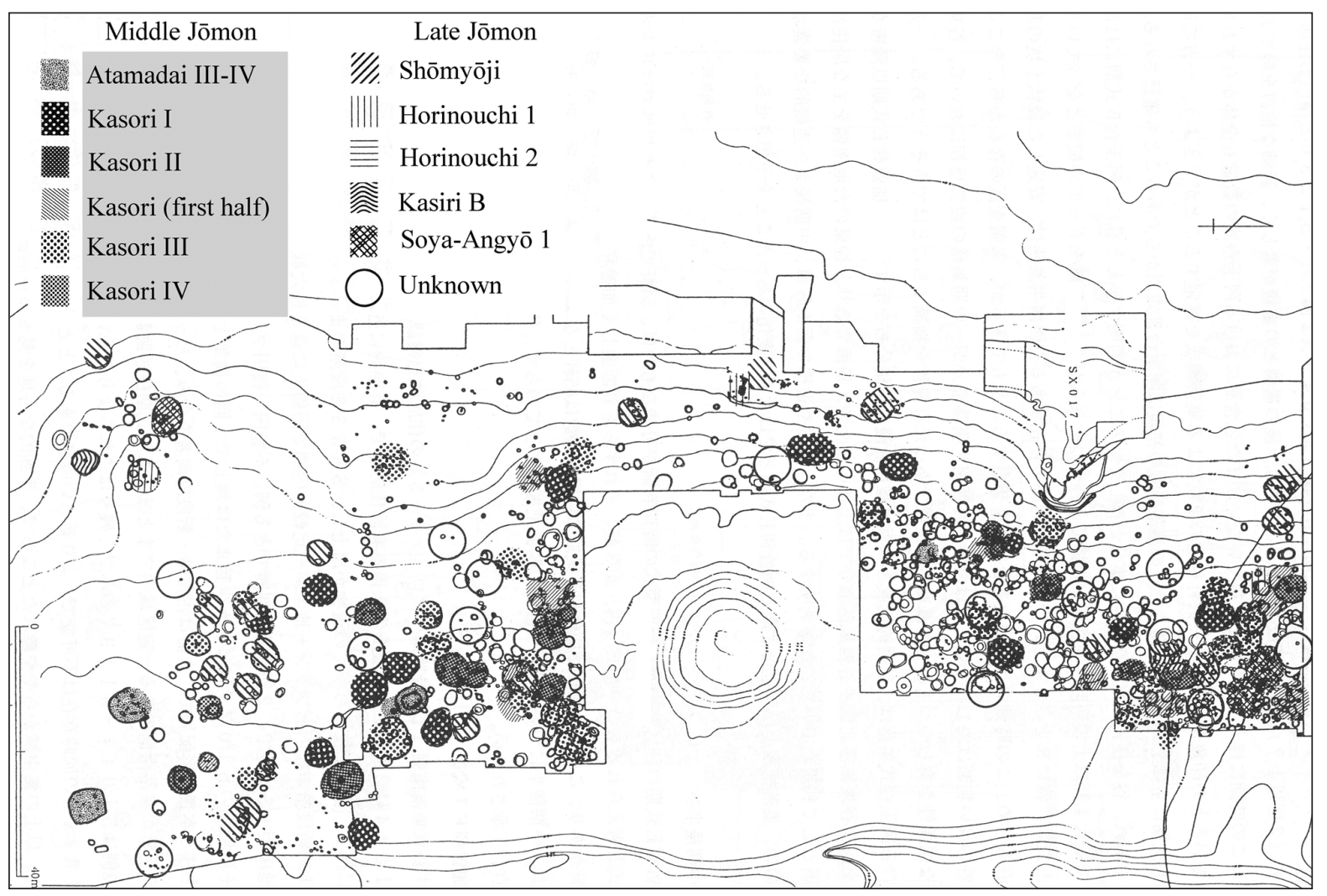

Fig. 1. Distribution of pit houses in the southern part of Teranohigashi (after Ehara 2001.Fig. 856). 


\section{Measures of rigidity: inte- gration}

Again, it is difficult to define the population of aggregated sites. These range from a few houses to more than 10 houses, according to the previous references. Medium-size settlements could consist of up to 130 people. The percentage of population in aggregated sites would have been approximately $70 \%$ in terms of the number of houses.

\section{Measures of rigidity: hie- rarchy}

Household difference is not clearly observable, although hierarchy or social complexity after the Late Jomon is a subject for discussion. Public architecture does not appear in the Kanto region in the Middle Jōmon. Differences in burial treatment are not apparent. There were various types of burial, such as pit burial and burial in abandoned houses. At the TNT no. 446 site, it is assumed that household heads were buried in pit graves which are located at the centre of the settlement, because this fits the number of houses from the same site (Fig. 2) (Abiko 2011.33). This calculation seems to be based on the idea that people stayed at the settlement throughout the year.

\section{Measures of rigidity: conformity}

Conformity can be assessed by material homogeneity. Pottery has similar forms, but with many variations in decoration. In the Kanto region, Kasori $\mathrm{E}$ pottery type is dominant. At least two pottery types have been found in the Tohoku region in the north, and the Chubu region in the west. A certain amount of such pottery has been found in neighboring regions. In the Middle Jōmon, household architecture remained homogeneous, and no critical differences in the structure and size of pit houses appear.

\section{Conclusion}

I used the variables in the study of Hegmon et al. (2008). Not every variable is useful for calculating the degree of rigidity in the Middle Jōmon, but they can be useful when comparing its rigidity with other periods. In this paper, I chose the Middle Jōmon period as a whole, although regional diversity and temporal differences are present even in the Kanto re- gion. For further research, we should explore more detailed data to clarify certain features of social change, such as the process of reorganisation and depopulation at the end of the Middle Jōmon.

Compared with the Late-Final Jōmon, the Middle Jōmon seems to have been less rigid and therefore more resilient. In the case of the US Southwest, Mimbres is thought to have experienced the least severe transformation of these regions. In contrast, Hohokam shows high rigidity. This could be related to the irrigation system, which limits population mobility. The depopulation of the Middle Jomon society seems to have been more rapid than in the Late-Final Jōmon, so we should consider what happened at the end of the Middle Jōmon and whether the Middle Jōmon society was resilient and able to reorganise.

The variables used to examine rigidity can be also applied to simple hunter-gatherers. So, for a more detailed examination, we need to improve and create more variables to understand rigidity among such societies.

While Middle Jōmon society exhibits a certain degree of rigidity, the Middle Jomon should be compared with other Jomon societies, or other periods in the same region in order to clarify the degree of rigidity. We can then consider whether Middle Jōmon society merely disappeared or underwent reformation. 


\section{References}

Abe A. 2008. Jōmonjidai no shakaihendōron. UM Promotion. Tokyo. (in Japanese)

Abiko S. 2011. Jōmon chūki shūraku no keikan. UM Promotion. Tokyo. (in Japanese)

Ehara E. 2001. Teranohigashi III. Tochigiken kyōikuiinkai/Tochigi shōgaigakushū bunka zaidan maizōbunka zaidan. Utsunomiya. (in Japanese)

Gunderson L. H., Holling C. S. 2002. Panarchy: understanding transformations in human and natural systems. Island Press. Washington, D.C.

Hegmon M., Peeples M., Kinzig A., Kulow S., Meegan C. M. and Nelson M. C. 2008. Social transformation and its human costs in the prehispanic U. S. Southwest. American Anthropologist 110: 313-324.

Imamura K. 1997. Jōmon jidai no jūkyoshisū to jinkō no hendō. In T. Fujimoto (ed.), Jū no kōkogaku. Dōseisha, Tokyo: 45-60. (in Japanese)

Kawashima T. 2009. Jōmon jidai kōbanki ni okeru shokuryō kakō shōhi no zōdai. Asian and African Studies 13: 257-282. (in Japanese)

Kobayashi T. 1985. Jōmon bunka no shūen. In Yawataichirō sensei shōju kinen kōkogaku ronshū henshūiinkai (ed.), Nihonshi no reimei. Rokkōshuppan. Tokyo: 231253. (in Japanese)

Sasaki Y. 2007. Shujitsu to dobokuyōzai kara mita Jōmon jidai chūkikōhan kara banki no shinrinshigen riyō: kantōheiya wo chūshin toshite. In M. Anzai, R. Takahashi (eds.), Jōmon jidai no shakai kōkogaku. Dōseisha, Tokyo: 211-237. (in Japanese)
Schollmeyer K. G. 2011 Large game, agricultural land, and settlement pattern change in the eastern Mimbres area, southwest New Mexico. Journal of Anthropological Archaeology 30: 402-415.

Suzuki Y. 1986. Chūbu minami Kantō ni okeru Jōmon shūraku no hensen. Kōkogakuzasshi 71(4): 30-53. (in Japanese)

1991. Kantō Chūbu chihō ni okeru Jōmon jidai no shūraku. Yoneshirokōko 7: 1-22. (in Japanese)

Teshigawara A. 1992. Social structure of the Jomon Period: analysis of the Middle Jomon sites at the southwestern skirt of Yatsugatake. Kōkogakuzasshi 78(1): 1-44. (in Japanese)

Yamamoto T. 1980. Jōmon jidai chūki shūmatsuki no shūraku. Kanagawakōko 9: 63-97. (in Japanese)

Yasuda K. 1981. Kikōhendō. In S. Katō, T. Kobayashi, T. Fujimoto (eds.), Jōmon bunka no kenkyū 1. Yūzankaku, Tokyo: 163-200. (in Japanese)

1997. Jōmon bunmei no kankyō. Yoshikawakōbunkan. Tokyo. (in Japanese)

Walker B., Salt D. 2006. Resilience Thinking: Sustaining Ecosystems and People in a Changing World. Island Press. Washington, D.C.

Walker B., Holling C. S., Carpenter S. R. and Kinzig A. 2004. Resilience, adaptability and transformability in social-ecological systems. Ecology and Society 9(2): 5. 